\title{
Effect of Pollination Method on Fruit Set in Commercial Cultivars of Litchi
}

\author{
Shweta Kumari $^{1 *}$, Ruby Rani ${ }^{1}$, J.C. Chandola ${ }^{2}$, Hidayatullah Mir ${ }^{1}$, \\ M. Feza Ahmad ${ }^{1}$ and Aditi Bharti ${ }^{1}$ \\ ${ }^{1}$ Department of Horticulture (Fruit and Fruit Technology), Bihar Agricultural University, \\ Sabour-813210, India \\ ${ }^{2}$ Department of Horticulture, College of Agriculture, GBPUAT, Pantnagar - 263145, India \\ *Corresponding author
}

\begin{tabular}{|l|}
\hline K e y w o r d s \\
$\begin{array}{l}\text { Pollination, Fruit } \\
\text { set, Cultivars, Litchi }\end{array}$ \\
\hline Article Info \\
\hline $\begin{array}{l}\text { Accepted: } \\
\text { 07 April } 2018 \\
\text { Available Online: } \\
\text { 10 May } 2018\end{array}$ \\
\hline \hline
\end{tabular}

A B S T R A C T

An experiment was conducted to study the effect of pollination methods on fruit set at Horticulture garden, BAU, Sabour. The effect of self, open and cross-pollination was studied in the four cultivars of litchi i.e. Deshi, Purbi, Bedana and Kasba. Five panicles/replication were bagged at flowering stage for selfing. Some panicles were tagged and left opened for open-pollination and some panicles having female flowers were bagged for making cross-combinations. It was clearly seen that in Deshi cultivar when open-pollinated having 222 female flowers, total fruit set was 47; in Purbi 314 flowers were kept for open-pollinated and in case of cv. Bedana when the number of female flowers were 141, the number of fruit set was 09 whereas in case of Kasba when 218 female flowers were left for open-pollination, the total number of fruit set was recorded to be 10. When five panicles were left for self-pollinated in all the four cultivars, the number of initial fruit set was maximum in case of Purbi (09) followed by Deshi (08), the minimum was found in Kasba (02). Due to the short time availability of flowers and lack of synchronization with respect to stages of flowering in four cultivars under study the possible cross-combinations were made. The numbers of flowers crossed in Deshi $x$ Bedana were 60 and the number of initial fruit set was 17. Similarly Purbi x Bedana, Purbi $\mathrm{x}$ Deshi and possible crosses were made and it was observed that when 12 flowers were crossed in the combination Kasba $x$ Bedana, the fruit set was nil. Similar was the case with Kasba x Purbi.

\section{Introduction}

Litchi, one of the most environmentally sensitive subtropical fruit crop, is adapted to areas of the world characterized by warm subtropics. China is the biggest producer of litchi, followed by India, Vietnam, and Thailand. Of the total production of litchi in India, $40 \%$ is contributed by Bihar. The major problem responsible for low economic potential of litchi cultivation is poor fruit set and inferior fruit quality (Gupta, 1991; Brahmachari et al., 1997). Other factors such as irregular flowering, heavy fruit drop, poor fruit retention, shy bearing, fruit cracking, small fruit size, low and irregular yields are reported wherever litchi have been grown, hampering its development as a major 
commercial crop (Menzel, 2001). These problems are attributed either failure to initiate flowers or failure to set fruit (Batten, 1986). Litchi flowering follows the pattern of "malefemale-male". The ratio of male to female flowers varies with the environment and among its various cultivars. High temperature during flower initiation reduces the proportion of female flowers (Cronje, 2009). The pattern of flowering would be expected to promote cross-pollination and prevent self-pollination. However, male (M1 and M2) and female (F) flowering stages may overlap on the same tree or between trees of the same cultivar, thereby providing an opportunity for self-pollination (Stern and Gazit, 2003). The results of pollination studies carried by Degani et al., (1995) indicated that pollen parent can have an effect on fruit-set, fruit retention and quality of litchi fruits.

\section{Materials and Methods}

The present investigation was carried out at Horticulture garden, BAU, Sabour during the year 2016-2017. Four cultivars i.e. Deshi, Purbi, Bedana and Kasba were chosen to study the effect of self, open and cross-pollination on fruit set in litchi. The experiment design used was Randomized Block Design with five replications per treatment. In self-pollination, total 2 randomly selected panicles were tagged and bagged in four different directions of the tree in each cultivar before anthesis and left as such upto the fruit set. Under open-pollination method, five panicles per replication were tagged in different directions and the number of fruit set was recorded in each treatment. The four cultivars were inter-crossed among themselves. 2 panicles were bagged with butter paper to avoid pollination with foreign pollen and the male flowers were removed by forceps every morning. Once the male flower opened, the pollens were collected for each combination in a Petridish and rubbed against the stigma of the bagged flowers.

\section{Results and Discussion}

The data on initial fruit set revealed that the pollination methods had pronounced effect on the fruit set of litchi. Fruit set was recorded to be highest in case of open-pollinated followed by cross-pollination. Poor self-compatibility was observed in all varieties under study.

From the table 1 it can be clearly seen that in Deshi cultivar when open-pollinated having 222 female flowers, total fruit set was 47; in Purbi 314 flowers were kept for openpollinated and in case of $\mathrm{cv}$. Bedana when the number of female flowers were 141, the number of fruit set was 09 whereas in case of Kasba when 218 female flowers were left for open-pollination, the total number of fruit set was recorded to be 10 . When five panicles were left for self-pollinated in all the four cultivars as shown in the table 2 . The number of initial fruit set was maximum in case of Purbi (09) followed by Deshi (08), the minimum was found in Kasba (02). Due to the short time availability of flowers and lack of synchronization with respect to stages of flowering in four cultivars under study following cross-combinations were made as depicted in table 3. The numbers of flowers crossed in Deshi x Bedana were 60 and the number of initial fruit set was 17. Similarly Purbi x Bedana, Purbi x Deshi and possible crosses were made and the result can be seen in table 3. When 12 flowers were crossed in the combination Kasba x Bedana, the fruit set was nil.

Similar was the case with Kasba $\mathrm{x}$ Purbi. Among the four cultivars, fruit set was recorded to be highest in case of openpollinated followed by cross-pollination. There was poor fruit set by selfing. In contrary to this result Brijwal et al., (2016) had reported that initial fruit set under selfpollination was significantly higher than all crosses and open-pollination methods. 
Int.J.Curr.Microbiol.App.Sci (2018) 7(5): 603-606

Table.1 Effect of open-pollination on fruit set

\begin{tabular}{|l|c|c|c|}
\hline Cultivars & $\begin{array}{c}\text { No. of female flowers } \\
\text { open-pollinated }\end{array}$ & No. of initial fruit set & \% of fruit set \\
\hline Deshi & 222 & 47 & 21.17 \\
\hline Purbi & 314 & 53 & 16.87 \\
\hline Bedana & 141 & 09 & 6.38 \\
\hline Kasba & 218 & 10 & 4.58 \\
\hline C.D at 5\% & 33.06 & & \\
\hline C.V. & 8.81 & & \\
\hline
\end{tabular}

Table.2 Effect of self-pollination on fruit set

\begin{tabular}{|l|l|c|c|}
\hline Cultivars & $\begin{array}{l}\text { Open/ Crossed/ Self } \\
\text { pollinated }\end{array}$ & $\begin{array}{c}\text { No. of panicles } \\
\text { bagged /replication }\end{array}$ & $\begin{array}{c}\text { No. of initial fruit } \\
\text { set }\end{array}$ \\
\hline Deshi & Self-pollinated & 5 & 08 \\
\hline Purbi & Self-pollinated & 5 & 09 \\
\hline Bedana & Self-pollinated & 5 & 04 \\
\hline Kasba & Self-pollinated & 5 & 02 \\
\hline
\end{tabular}

Table.3 Effect of cross-pollination on fruit set

\begin{tabular}{|l|l|c|c|}
\hline Cultivars & $\begin{array}{l}\text { Open/ Crossed/ Self } \\
\text { pollinated }\end{array}$ & $\begin{array}{c}\text { No. of flowers } \\
\text { crossed }\end{array}$ & $\begin{array}{c}\text { No. of initial } \\
\text { fruit set }\end{array}$ \\
\hline Deshi x Bedana & Cross-pollinated & 60 & 17 \\
\hline Purbi x Deshi & Cross-pollinated & 23 & 02 \\
\hline Purbi x Bedana & Cross-pollinated & 32 & 16 \\
\hline Bedana x Purbi & Cross-pollinated & 32 & 08 \\
\hline Kasba x Deshi & Cross-pollinated & 17 & 01 \\
\hline Kasba x Purbi & Cross-pollinated & 12 & 00 \\
\hline Kasba x Bedana & Cross-pollinated & 14 & 00 \\
\hline
\end{tabular}

Forneman et al., (2012) also reported the lower initial fruit set in all cross-pollination as compared to self-pollination in 'Wai Chee' litchi cultivar. Mc Conchie and Batten (1991) had suggested that the most appropriate time for fruit to be considered set is when most fruit left on a panicle reach maturity.

Fruit set was recorded to be highest in case of open-pollinated followed by cross-pollination. Poor self-compatibility was observed in all varieties under study.

\section{Acknowledgements}

It is proud privilege to express my most sincere and profound sense of gratitude to my Major Advisor and Chairman of my Advisory committee Dr. Ruby Rani, Assistant Professor cum Junior Scientist, Department of Horticulture (Fruit and Fruit Technology), Bihar Agricultural University, Sabour, Bhagalpur for her inspiring, nobel guidance, untiring help, keen interest, constant painstaking efforts, constructive criticism, 
constant encouragement and in carrying out the research and preparation of this manuscript also for providing necessary facilities to carry out the research work in an effective manner, which has made orientation of this memory of my life.

\section{References}

Batten, D.J. 1986. Maturity criteria for litchi (Lychee). Food Quality and Preference, 1: 149-155.

Brahmachari, V.S. and Kumar, Rajesh. 1997. Effect of foliar sprays of mineral nutrients on fruit set, retention and cracking of litchi (Litchi chinensis Sonn.) fruits. Haryana J.Hort.Sci. 26(34):80.

Brijwal, M., Dimri D.C., Mishra, D.S. and Narayan, A. 2016. Flowering and pollen morphological studies in some litchi (Litchi chinensis Sonn.) cultivars Res. on Crops, 17 (2): 283-290.

Cronje R.B., Shivakumar D., Mostert P.G and Korsten L. 2009. Effect of different preharvest treatment regimes on fruit quality of litchi cultivar 'Mauritius' Journal of Plant Nutrition, 32:19-29.
Degani, C., Stern R.A., El-Bastri R. and Gazit, S. 1995. Pollen parent effect on the selective abscission of Mauritius and Floridian lychee fruits. J. American Soc. Hort. Sci., 120: 523-26.

Froneman, I.J., Bijzet, Z. and Sippel, A.D. 2012. Effect of different pollen parents on fruit retention and fruit characteristics in 'Wai Chee' litchi. Acta Hort., 932: 51-58.

Gupta, S.P. 1991. Floral biology and fruit drop studies of litchi (Litchi chinensis Sonn.). Thesis, M.Sc. SKUAST-K J\&K, India.

McConchie, C.A. and Batten, D.J. 1991. Fruit set in lychee (Litchi chinensis Sonn.) variation between flower panicles and tree. Australian Journal of Agricultural and Resource Economics, 42: 11631172.

Menzel, C.M. 2001. The physiology of growth and cropping in lychee. South African Litchi Growers' Association Yearbook, 12: 9-14.

Stern, R.A. and Gazit, S. 2003. The reproductive biology of the lychee. Hort. Rev., 28: 393-53.

\section{How to cite this article:}

Shweta Kumari, Ruby Rani, J.C. Chandola, Hidayatullah Mir, M. Feza Ahmad and Aditi Bharti. 2018. Effect of Pollination Method on Fruit Set in Commercial Cultivars of Litchi. Int.J.Curr.Microbiol.App.Sci. 7(05): 603-606. doi: https://doi.org/10.20546/ijcmas.2018.705.074 